\begin{tabular}{|l|l|l|l|l|l|} 
J. Tek. Ling & Vol.11 & No.2 & Hal. 247 - 253 & Jakarta, Mei 2010 & ISSN 1441-318X \\
\hline
\end{tabular}

\title{
PENGARUH PENAMBAHAN STARTER TERHADAP KARAKTERISTIK PROSES PENGOMPOSAN DAN KUALITAS KOMPOS LIMBAH PABRIK AGAR
}

\author{
Firman L. Sahwan \\ Peneliti di Pusat Teknologi Lingkungan \\ Badan Pengkajian dan Penerapan Teknologi
}

\begin{abstract}
Solid waste from "agar-agar" (gelation made of seaweed) factory in huge amount and has potency to pollute the environment if it is not well managed, obviously has opportunity to be used as compost. The purpose of this research is to find out the characteristic of composting process of agar-agar factory's waste, and the quality of its compost product, based on 2 (two ) treatments i.e. with and without the use chicken manure starter. In general, result of the research showing that there is no significant different between using chicken manure starter and not using chiken manure starter, with understanding that both composting process can be done in aerobic condition (normal) with compost quality according to mature compost criteria. However, specifically the rate of waste decomposition (composting process) of using chicken manure starter looks faster in initial period of decomposition.
\end{abstract}

Key words : compost, "agar-agar" factory waste, chiken manure starter.

\section{PENDAHULUAN}

\subsection{Latar Belakang}

Industri agar, karaginan dan alginat di Indonesia yang bahan bakunya berasal dari rumput laut, akan terus berkembang karena produksi dalam negri belum bisa mencukupi kebutuhan dalam negri maupun untuk memenuhi kebutuhan ekspor. Saat ini tercatat paling tidak ada 16 industri yang beroperasi dan sedang berproduksi di Indonesia.1)

Selain faktor kebutuhan akan agar, karaginan dan alginat yang tinggi, maka potensi dan sebaran rumput laut di Indonesia juga sangat tinggi. Luas perairan laut Indonesia serta keragaman jenis rumput laut yang terdiri dari 782 jenis, merupakan cerminan dari potensi rumput laut Indonesia. Produksi rata-rata rumput laut (Eucheuma dan Gracilaria) Indonesia pertahun sebanyak 38.000 ton (1995-1999), baru berasal dari $9,7 \%$ potensi lahan yang ada ${ }^{1)}$

Daerah sebaran beberapa jenis rumput laut di Indonesia sangat luas, baik yang tumbuh secara alami maupun yang dibudidayakan. Wilayah sebaran rumput laut yang tumbuh alami (wild stock) terdapat di hampir seluruh perairan dangkal laut Indonesia yang mempunyai rataan terumbu karang. ${ }^{1)}$

Seperti halnya umumnya kegiatan industri, maka kegiatan industri pengolahan rumput laut menjadi agar, keraginan dan alginat akan menghasilkan limbah, khususnya limbah padat, yang jika tidak dikelola dengan baik dan benar akan berpotensi mencemari lingkungan. Jumlah limbah padat yang dihasilkan cukup besar. Sebagai gambaran 
PT. Agarindo Bogatama menghasilkan limbah padat sekitar 60 ton per hari. Limbah padat tersebut dikumpulkan secara open dumping di sekitar area pabrik.

Permasalahan lingkungan, saat ini bisa menjadi sandungan dalam persaingan global industri agar, karaginan dan alginat. Untuk itu dalam proses produksinya perlu dicarikan alternatif penanganan limbah padatnya agar tidak mencemari lingkungan, bahkan diharapkan bisa memberikan nilai tambah. Salah satu opsi yang bisa dilakukan adalah memanfaatkan limbah padat tersebut menjadi pupuk organik kompos melalui suatu proses pengomposan. Dalam bidang pertanian, pupuk kompos yang merupakan salah satu pupuk organik utama, sangat diperlukan untuk meningkatkan kesuburan lahan dan kesehatan tanaman, melalui perbaikan sifat fisik, kimia dan biologi sumberdaya lahan.

Proses pengomposan merupakan proses penguraian materi organik yang kompleks, yaitu materi yang berasal dari mahluk hidup, secara biologis (dilakukan oleh konsorsium mikroorganisme) menjadi materi organik yang sederhana dan relatif stabil menyerupai humus (biasa disebut dengan kompos) dalam kondisi yang tekendali ${ }^{2-5}$. Prosesnya dikendalikan dengan menjaga keseimbangan $\mathrm{C} / \mathrm{N}$ ratio, kadar air, suhu, $\mathrm{pH}$, konsentrasi oksigen, dan lain-lain ${ }^{6}$.

\subsection{Tujuan Penelitian}

Tujuan dari penelitian ini adalah untuk mengetahui karakteristik dari proses pengomposan limbah padat pabrik agar, serta mengetahui kualitas produk komposnya, berdasarkan dua perlakuan yaitu dengan dan tanpa penggunaan starter kotoran ayam

\section{METODOLOGI}

\subsection{Tempat dan Waktu Penelitian}

Penelitian dilakukan di Pilot Plant
Pengomposan pabrik agar dari rumput laut PT. Agarindo Bogatama, Pasar Kemis, Tangerang, pada tanggal 18 Januari sampai 18 Maret 2008.

\subsection{Proses Pembuatan Kompos}

Dalam penelitian ini, starter yang digunakan adalah kotoran ayam. Starter biasa, alami atau yang sengaja dikembang biakan, juga disebut inoculant, merupakan kumpulan dari mikroorganisma yang diharapkan dapat berfungsi untuk mempercepat proses pengomposan dan memperkaya keanekaragaman mikroba ${ }^{6}$.

Proses pengomposan dalam penelitian ini dilakukan dengan sistem open windrow dengan lama waktu proses pembuatan sekitar 6-7 minggu. Limbah padat dari pabrik agar yang akan digunakan dalam penelitian langsung ditumpuk dengan dimensi ukuran tumpukan $5 \times 2,5 \times 1,5$ meter sebanyak 2 (dua) tumpukan.

Tumpukan pertama atau disebut dengan (LA 1X) merupakan tumpukan limbah dengan total berat 5,93 ton yang ditambahkan dengan kotoran ayam seberat 0,355 ton atau sebanyak $6 \%$ berat. Sedangkan tumpukan kedua merupakan tumpukan yang murni limbah dengan tanpa penambahan kotoran ayam, disebut dengan ( $\mathrm{L} 1 \mathrm{X})$. Tumpukan kedua ini ( $L$ 1X) didalam penelitian berfungsi sebagai kontrol.

Filosofi penambahan kotoran ayam terutama dalam rangka menambahkan mikroba alami (sebagai starter) selain penambahan unsur $\mathrm{N}$ terhadap limbah pabrik agar yang akan dikomposkan. Hal ini dianggap perlu karena limbah agar yang dipakai adalah limbah yang langsung keluar dari pabrik. Sedangkan dalam proses pembuatan produk agar-agar di pabrik melibatkan proses pasteurisasi, sehingga limbah yang dihasilkan dianggap steril atau miskin mikroba pengurai.

Terhadap kedua tumpukan tersebut dilakukan proses pembalikan 1 kali dalam 1 minggu yang merupakan frekuensi 
pembalikan yang dianggap optimal6). Kadar air di pertahankan pada sekitar $60 \%$ yang merupakan kadar air optimal ${ }^{2-5)}$ dengan cara melakukan penyiraman air apabila kadar airnya menurun.

\subsection{Parameter Pengamatan}

Parameter yang diamati dalam pnelitian ini antara lain suhu tumpukan dan suhu udara harian serta volume tumpukan yang dilakukan setiap minggu sekali. Pada saat penelitian berlangsung dilakukan juga pengamatan perubahan warna, bau dan perubahan struktur dari limbah.

Pada. awal penelitian dilakukan analisa laboratorium terhadap kadar air, $\mathrm{pH}$, kandungan $\mathrm{N}$ dan $\mathrm{C}$ organik. Sedangkan pada akhir penelitian dilakukan analisa laboratorium untuk mengetahui kadar air (KA), pH, kandungan $\mathrm{N}, \mathrm{NH}_{3}, \mathrm{NO}_{3}, \mathrm{P}_{2} \mathrm{O}_{5}$, $\mathrm{K}_{2} \mathrm{O}$, C organik, kadar garam total ,kadar $\mathrm{NaCl}$ dan $\mathrm{C} / \mathrm{N}$ ratio. Selain itu terhadap tumpukan yang sudah dianggap menjadi kompos dilakukan pengamatan terhadap warna, bau dan strukturnya.

Secara garis besar proses pengomposan limbah padat pabrik agar dalam penelitian ini dapat digambarkan pada diagram dalam Gambar1.

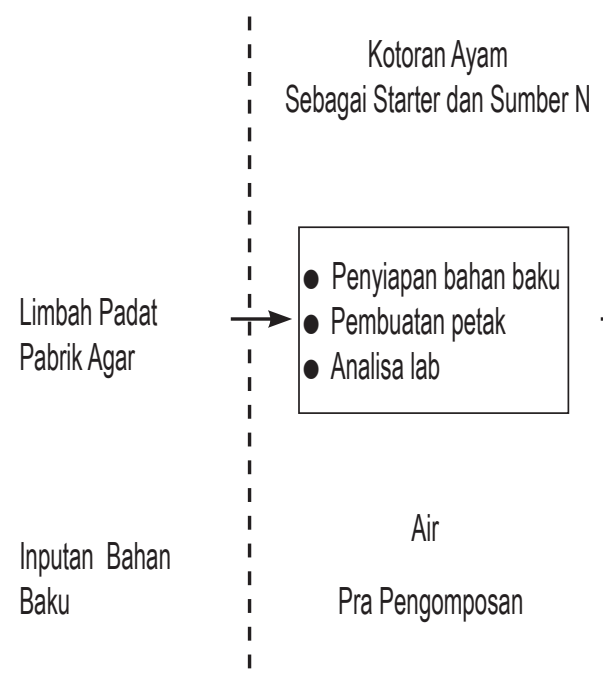

\section{HASIL DAN PEMBAHASAN}

\subsection{Pengamatan Struktur, Bau dan Warna}

Pada awal penelitian, struktur dari limbah yang diteliti berbentuk bongkahan/ lempengan. Pada minggu ke dua terlihat terjadi pemecahaan bongkahan menjadi struktur bongkahan yang lebih kecil. Pada minggu ke tiga bongkahan/lempengan limbah pecah menjadi struktur yang lebih kecil lagi bahkan hancur berbentuk seperti pasir. Pada akhir minggu ke tiga struktur bahan sudah hancur semua dan berbentuk seperti pasir. Perubahan struktur tersebut sedikit lebih cepat terjadi pada limbah yang ditambah dengan kotoran ayam (LA 1X). $\mathrm{Hal}$ ini memperlihatkan adanya pengaruh starter terhadap proses pengomposan karena bahan yang dikomposkan miskin mikroba ${ }^{6}$, sebagai akibat adanya proses pasteurisasi pada saat proses produksi agar-agar, yang berdampak pada matinya mikroba bermanfaat (fungsional pada proses pengomposan).

Bahan dengan struktur seperti pasir pada produk kompos diduga berasal dari selite yang sengaja ditambahkan pada proses pengolahan rumput laut menjadi agar. Dengan struktur

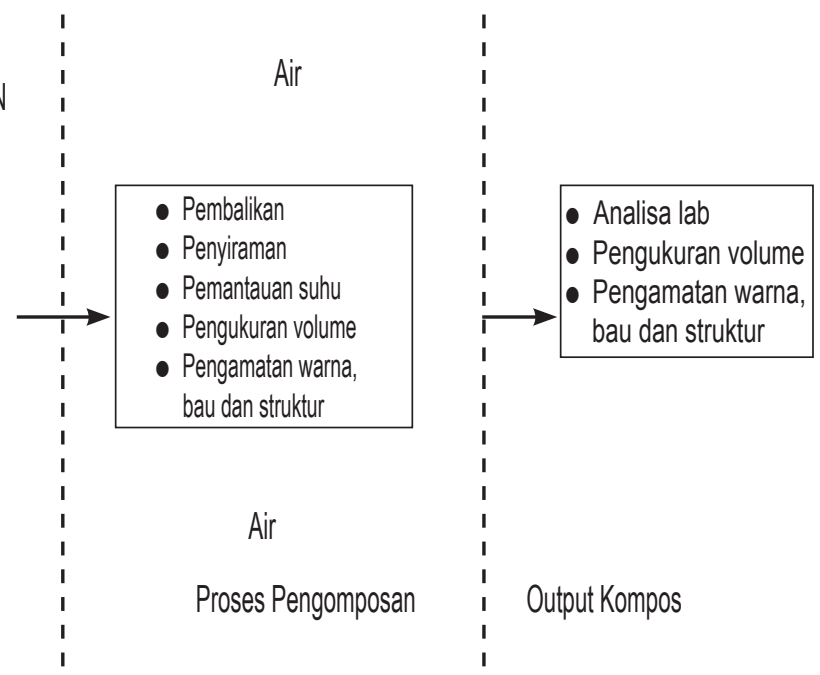

Gambar 1 Diagram Proses Penelitian Pengomposan Limbah Pabrik Agar 
produk kompos yang banyak mengandung pasir, mengindikasikan banyaknya penggunaan selite pada proses pembuatan agar, yang akan berpengaruh terhadap kualitas produk komposnya. Tingginya kandungan selite/pasir pada produk kompos dapat berpengaruh positif ataupun negatif terhadap kualitas produk yang dihasilkan, tergantung kepada pemanfaatan dari produk tersebut.

Untuk bau dan warna dari produk kompos yang diteliti, ternyata agak berbeda bila dibandingkan dengan produk kompos pada umumnya. Produk komposnya berbau seperti aroma pesisir dan tidak berbau seperti kompos matang pada umumnya yang berbau seperti tanah humus, sedangkan warnanya cenderung coklat muda dan bukan coklat kehitaman. Tidak ada perbedaan yang nyata antara yang ditambah kotoran ayam dengan yang tanpa kotoran ayam.

Gambaran struktur, bau dan warna dari produk kompos yang diteliti mengindikasikan bahwa kandungan bahan organiknya sangat rendah. Hal ini sesuai dengan hasil analisis C organiknya.

\subsection{Dinamika Temperatur Selama Proses Pengkomposan}

Dinamika temperatur memainkan peranan yang paling penting dalam proses pengomposan, karena menggambarkan indikator dari dinamika aktivitas mikrobiologi ${ }^{7}$. Oleh karena itu profil perubahan temperatur menggambarkan pula karakterisitk dari proses pengkomposan yang sedang berjalan, bahkan menjadi parameter kunci kematangan kompos. Kompos dikatakan matang apabila temperatur dari tumpukan bahan yang dikomposkan tidak lebih dari $20^{\circ} \mathrm{C}$ di atas temperatur udara. Dinamika temperatur selama proses pengomposan disajikan pada Gambar 2.

Dinamika temperatur benar-benar menjadi parameter kunci dalam penelitian ini. Tumpukan limbah yang menggunakan starter kotoran ayam terlihat lebih responsif atau lebih dinamis perubahan temperaturnya. Dalam satu minggu pertama temperatur tumpukan sudah bisa mencapai $70{ }^{\circ} \mathrm{C}$ dan merupakan temperatur paling tinggi (puncak). Sedangkan yang tanpa kotoran ayam, suhu tertingginya sekitar $60{ }^{\circ} \mathrm{C}$ baru dicapai setelah 3 minggu proses pengomposan. Meningkatnya temperatur, menggambarkan aktivitas mikroba, yaitu sebagai hasil dari proses metabolisme melalui respirasi dan terinsulasi oleh material yang dikomposakan. ${ }^{7}$.

Miskinnya mikroba pada limbah

Gambar 2. Dinamika Temperatur Selama Proses Pengomposan

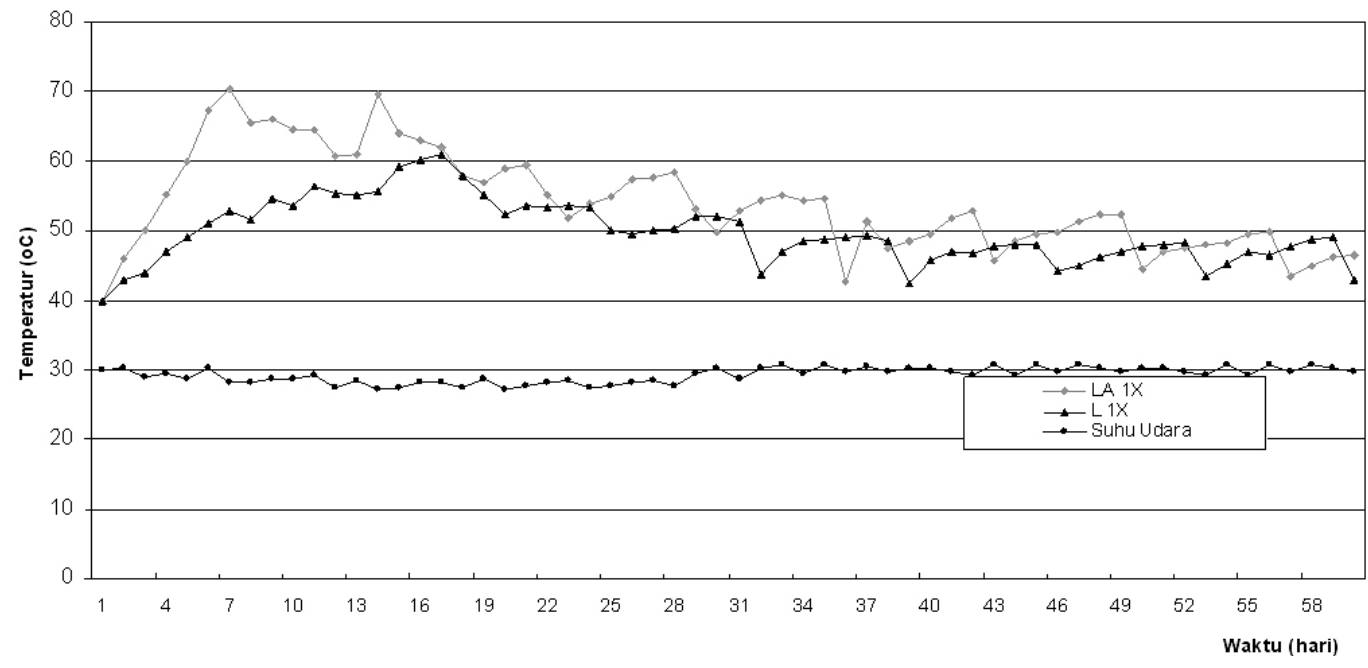


yang dikomposkan sebagai akibat proses pasteurisasi di pabrik, membuat penambahan starter kotoran ayam sangat berpengaruh untuk memancing perkembangan mikroba yang lebih cepat pada limbah yang dikomposkan, terutama pada awal-awal proses. Kondisi tersebut juga sesuai dengan kecepatan penguraian struktur material yang lebih cepat hancur pada limbah yang ditambahkan kotoran ayam.

Temperatur dibawah $50{ }^{\circ} \mathrm{C}$ yang merupakan kondisi telah matangnya limbah yang dikomposkan, dicapai setelah 5 minggu proses pengomposan. Secara umum proses pengomposan berlangsung selama $6-7$ minggu $^{6}$. Kondisi demikian menggambarkan bahwa proses pengomposan limbah pabrik agar berlangsung lebih cepat.

Kalau dicermati lebih mendalam, kondisi di atas disebabkan oleh bahan baku yang mudah hancur, selain kandungan bahan organik dari limbah yang dikomposkan sangat rendah, seperti dipresentasikan oleh kandungan $\mathrm{C}$ organik yang cuma sekitar $2 \%$. Dengan materi organik yang sangat sedikit, maka mikroba pengurai yang telah melewati aktivitas puncaknya, akan dengan cepat kehabisan bahan makanan, sehingga aktivitasnya menjadi jauh menurun yang digambarkan dengan penurunan temperatur di bawah $50{ }^{\circ} \mathrm{C}$. Kondisi demikian terjadi setelah 5 minggu proses pengomposan berlangsung, yang juga menggambarkan waktu proses pengomposan telah selesai atau telah dihasilkan kompos yang sudah matang. Tidak ada perbedaan yang nyata tentang waktu yang dibutuhkan untuk proses pengomposan, antara limbah yang menggunakan starter kotoran ayam atau yang tidak.

\subsection{Reduksi Volume Selama Proses Pengkomposan}

Proses penguraian materi organik oleh mikroba telah mengakibatkan terjadinya reduksi volume karena sebagian besar dari unsur karbon pada materi organik diubah menjadi $\mathrm{CO}_{2}{ }^{7}$. . Reduksi volume juga disebabkan oleh proses pembalikan dan penguraian material limbah organik sehingga ukuran partikel semakin kecil dan semakin padat. Untuk itu reduksi volume yang utamanya merupakan akibat proses biokimia dari mikrobiologi pengomposan dapat juga dipakai sebagai salah satu parameter menentukan kematangan suatu proses pengomposan. Kompos dikatakan matang apabila reduksi volumenya melampaui 60 $\%{ }^{8)}$.

Proses reduksi (penyusutan) volume pada pengomposan limbah pabrik agar berjalan sangat lambat dan dalam persentase yang kecil bila dibandingakan dengan reduksi volume pengkomposan limbah yang lain. Berdasarkan kriteria temperatur pengomposan limah pabrik agar sudah dikatakan matang setelah minggu ke 5 . Pada kondisi tersebut reduksi volume masih berada di bawah $60 \%$. Pada akhir penelitian ( 8 minggu) reduksi volume baru mencapai $50-60 \%$.

Rendahnya reduksi volume pada pengomposan limbah pabrik agar diduga karena banyaknya materi an organik dan tidak terurai selama proses pengomposan. Bahan itu kemungkinan besar adalah materi yang ditambahkan pada proses pengolahan rumput laut menjadi agar, yakni selite. Kondisi tersebut didukung oleh rendahnya kandungan $\mathrm{C}$ organik pada bahan baku.

Kondisi limbah yang telah menyebabkan rendahnya reduksi volume, mengakibatkan tidak validnya reduksi volume untuk digunakan sebagai parameter kematangan kompos Bahan baku yang digunakan adalah limbah pabrik agar segar atau yang baru keluar dari proses pabrik. Kualitas fisik dan kimia bahan baku disajikan dalam Tabel 1. 
Gambar 3. Profil Volume Proses Pengkomposan

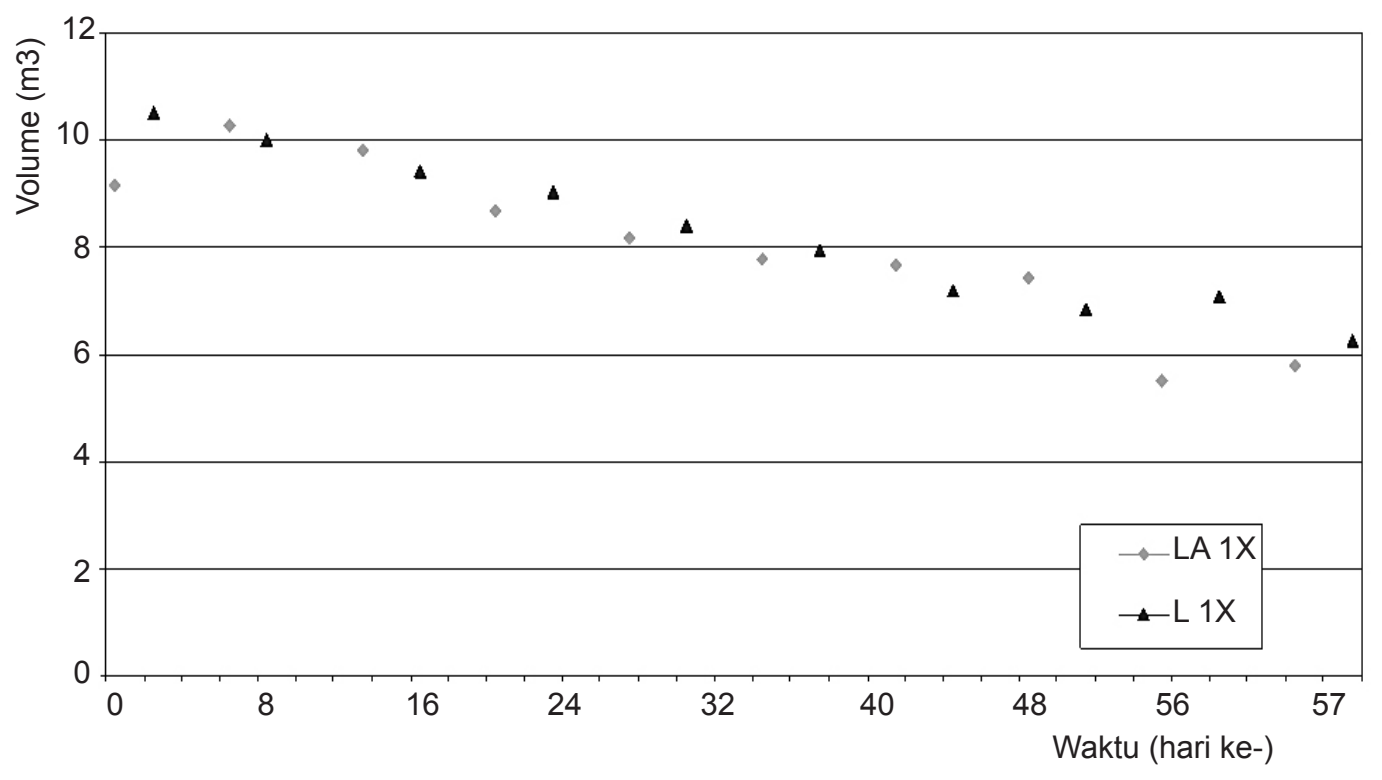

Tabel 1. Kualitas Fisik dan Kimia Bahan Baku Limbah Pabrik Agar

\begin{tabular}{|l|l|l|l|}
\hline No & \multicolumn{1}{|c|}{ Parameter } & Satuan & \multicolumn{1}{c|}{ Nilai } \\
\hline 1 & $\mathrm{pH}$ & & 5,6 \\
2 & Kadar air & $\%$ & 60 \\
3 & Nitrogen & $\%$ & 0,4 \\
4 & Karbon organik & $\%$ & 2,4 \\
5 & C/N ratio & & 6 \\
\hline
\end{tabular}

\subsection{Kualitas Bahan Baku dan Produk Kompos}

Berdasarkan data pada Tabel 1, terlihat ada kendala utama pada bahan baku yaitu kandungan karbon organik yang sangat rendah (2,4\%). Sangat rendahnya kandungan C organik, mengindikasikan bahwa di dalam bahan baku mengadung materi an organik yang tinggi. Bahan an organik tersebut terutama selite yang sengaja ditambahkan dalam proses pembuatan agar di dalam pabrik.

Kandungan $\mathrm{N}$ bahan baku juga rendah $(0,4 \%)$. Tetapi nilai tersebut kalau dijadikan nilai ratio perbandingan dengan $\mathrm{C}$ akan menghasilkan $\mathrm{C} / \mathrm{N}$ ratio 6 yang menunjukan nilai $\mathrm{C} / \mathrm{N}$ ratio yang terlalu rendah. Ratio
$\mathrm{C} / \mathrm{N}$ tersebut mengindikasikan nilai $\mathrm{N}$ yang masih terlalu tinggi sebagai akibat nilai $\mathrm{C}$ yang terlalu rendah. Nilai $\mathrm{C} / \mathrm{N}$ rasio optimal adalah $30: 1^{2,5)}$.

Dari kualitas bahan baku seperti tersebut di atas, maka ke depan apabila pihak pabrik akan memproduksi kompos secara rutin, sebaiknya terhadap bahan baku dicampur dengan limbah-limbah yang lain atau ditambahkan dengan bahan baku yang kaya akan bahan organik, terutama $\mathrm{C}$ organik.

Untuk kualitas fisik dan kimia dari produk kompos yang dihasilkan dapat dilihat pada Tabel 2. Berdasarkan data pada Tabel 2, maka nilai $\mathrm{C}$ organik yang sangat rendah (2,08 dan 2,0 ) perlu mendapat perhatian utama. Rendahnya nilai $\mathrm{C}$ organik menggambarkan bahwa kandungan materi an organik dalam kompos terutama selite yang sengaja ditambahkan dalam proses pembuatan agar, terlalu tinggi.

Begitu juga dengan kandungan $\mathrm{N}$ yang $0,16 \%$ terlalu rendah. Sebagai perbandingan nilai $\mathrm{N}$ kompos dari limbah Rumah Pemotongan Hewan Cakung adalah $2,48 \%^{9}$. Sedangkan nilai $\mathrm{N}$ kompos dari sampah kota adalah 14,92 - 17,76 \% di 
Tabel 2. Kualitas Fisik dan Kimia Produk Kompos

\begin{tabular}{|c|c|c|c|c|c|}
\hline \multirow[b]{2}{*}{ No } & \multirow[b]{2}{*}{ Parameter } & \multirow[b]{2}{*}{ Satuan } & \multicolumn{2}{|c|}{ Nilai Kompos } & \multirow[b]{2}{*}{ SNI Kompos } \\
\hline & & & $\begin{array}{c}\text { Dengan Kotoran Ayam } \\
\text { (LA 1X) }\end{array}$ & $\begin{array}{c}\text { Tanpa Kotoran Ayam } \\
(\mathrm{L} 1 \mathrm{X})\end{array}$ & \\
\hline 1 & Kadar Air & $\%$ & 61,82 & 61,05 & $\max 50$ \\
\hline 2 & $\mathrm{pH}$ & & 8,2 & 8,0 & $6,8-7,49$ \\
\hline 3 & $\mathrm{~N}$ & $\%$ & 0,16 & 0,16 & $\min 0,4$ \\
\hline 4 & $\mathrm{P}_{2} \mathrm{O}_{5}$ & $\%$ & 1,28 & 1,30 & $\min 0,1$ \\
\hline 5 & $\mathrm{~K}_{2} \mathrm{O}$ & $\%$ & 1,40 & 1,40 & $\min 0,2$ \\
\hline 6 & C organik & $\%$ & 2,08 & 2,0 & $9,8-32$ \\
\hline 7 & Kadar garam & $\%$ & 0,07 & 0,06 & \\
\hline 8 & $\mathrm{C} / \mathrm{N}$ ratio & & 13 & 12,5 & $10-20$ \\
\hline
\end{tabular}

Rawasari Jakarta ${ }^{(10)}$ dan 2,0 - 2,15\% di Buleleng Bali ${ }^{11)}$.

Kadar air yang $\pm 60 \%$ masih lebih tinggi dari yang di persyaratkan SNI kompos. Hal ini berarti perlu sedikit proses pengeringan lagi sebelum dikemas. Terlalu tingginya kadar air akan memudahkan tumbuhnya jamur pada kemasan, sehingga dapat mengurangi nilai estetika.

Untuk nilai $\mathrm{pH}$ yang \pm 8 , walaupun masih lebih tinggi dengan yang di persyaratkan SNI, masih menggambarkan nilai $\mathrm{pH}$ yang umum (normal) pada kompos yang sudah matang. Hal ini sering di temui pada kompos dari bahan limbah yang lain ${ }^{2-6)}$.

Nilai $\mathrm{C} / \mathrm{N}$ rasio yang merupakan salah satu parameter kompos matang, ternyata bisa dipenuhi, sehingga produk kompos limbah pabrik agar ini bisa dikatakan matang dan siap pakai. Hal ini juga sesuai dengan parameter temperatur yang juga sudah mencerminkan kompos matang.

Secara umum, kualitas kompos yang dengan atau yang tanpa starter kotoran ayam tidak berbeda nyata dan menunjukkan kualitas yang cukup baik, bila dilihat dari kematangan kompos. Namun kalau dilihat kandungan $\mathrm{C}$ organik yang sangat rendah mencerminkan kualitas kompos yang kurang baik, yaitu menggambarkan tingginya kontaminan (bahan asing) yang ada di dalam produk.

Tingginya kandungan pasir/selite pada produk kompos yang dihasilkan, maka untuk penggunaan komposnya, sebaiknya digunakan sebagai media tanam untuk tanaman yang memerlukan kandungan pasir yang tinggi atau difungsikan sebagai media tanam yang porous.

\section{KESIMPULAN DAN SARAN}

\subsection{Kesimpulan}

Berdasarkan hasil penelitian ini, disimpulkan :

1. Secara umum, kualitas produk kompos limbah pabrik agar cukup baik dalam pengertian proses pengomposannya berlangsung secara aerobik dan menghasilkan kompos yang memenuhi sebagian kriteria kompos matang. Namun kandungan $\mathrm{C}$ organik yang rendah menggambarkan tingginya kontaminan berupa pasir/ selite sehingga menurunkan kualitas kompos yang dihasilkan.

2. Kandungan materi anorganik bahan baku cukup tinggi sehingga berpengaruh terhadap kandungan materi anorganik produk komposnya yang juga tinggi (kontaminan). Materi anorganik tersebut berbentuk seperti pasir yang diduga berasal dari "selite" yang sengaja ditambahkan pada proses pembuatan agar dari rumput laut.

3. Kandungan hara Nitrogen ( $\mathrm{N}$ ) produk 
komposnya rendah, dibandingkan dengan produk kompos dari limbah yang lain.

4. Secara umum karakteristik pengomposan limbah pabrik agar serta kualitas produk komposnya antara yang menggunakan strater kotoran ayam dengan yang tidak relatif sama. Namun secara khusus pemberian starter kotoran ayam berpengaruh pada kecepatan penguraian limbah (proses pengomposan), pada periode awal pengomposan.

\subsection{Saran}

Berdasarkan hasil penelitian ini, disarankan :

1. Untuk produksi kompos selanjutnya, sebaiknya limbah pabrik agar dicampur dengan limbah organik yang lain.

2. Produk komposnya sebaiknya dijadikan media tanam untuk jenis tanaman yang membutuhkan media struktur pasir.

\section{DAFTAR PUSTAKA}

1. Anggadiredja, J.T., A. Zatnika, H. Purwoto dan S. Istini, 2009. Rumput Laut, Penebar Swadaya, Jakarta.

2. Epstein, E., 1997. The Science of Composting, Technomic Publishing Company Inc., USA

3. Golueke, C. G., 1997. Biological Processing : Composting and Hydrolysis; In Handbook of Solid Waste Management, Van Nostrand Reinhold Company, New York

4. Haug, R.T., 1980. Compost Engineering, Principles and Practice, An Arbor Science Publisher Inc., Michigan.

5. Tchobanoglous, G., H. Theisen and S. Vigil, 1993. Integrated Solid Waste Management, Engineering Principles and Management Issues, Mc Graw-
Hill Inc, USA

6. Wahyono, S., F.L. Sahwan dan F. Suryanto, 2003. Menyulap Sampah Menjadi Kompos, Pusat Pengkajian dan Penerapan Teknologi Lingkungan BPPT, Jakarta.

7. Wahyono, S., dan F.L. Sahwan, 2008. Dinamika Perubahan Temperatur dan Reduksi Volume Limbah dalam Proses Pengkomposan (Studi Kasus Pengomposan di RPH Cakung Jakarta Timur), Jurnal Teknologi Lingkungan, Pusat Teknologi Lingkungan 9 ( 3 ) : 255 - 262.

8. Anonim, 1996. Guidelines for Compost Quality, Canadian Council of Ministry of Environment.

9. Wahyono, S., F.L. Sahwan dan F. Schuchardt, 2003. Pembuatan Kompos dari Limbah Rumah Potong Hewan, Pusat Pengkajian dan Penerapan Teknologi Lingkungan, BPPT, Jakarta.

10. Sahwan, F.L, 2008. Pengelolaan Sampah Berbasis Masyarakat di TPST Rawasari, Pusat Teknologi Lingkungan, BPPT.

11. Sahwan, F.L, 2009. Teknologi Pengolahan Sampah Menjadi Kompos di Buleleng - Bali, Pusat Teknologi Lingkungan, BPPT.

12. Badan Standarisasi Nasional, 2004. Standar Nasional Indonesia Spesifikasi Kompos dari Sampah Organik Domestik. 